\title{
Cell Adhesion Molecule Expression in Human Lens Epithelial Cells After Corticosteroid Exposure
}

\author{
D. Celojevic ${ }^{1}$, T. Carlsson ${ }^{2}$, B.R. Johansson ${ }^{2}$, U. Nannmark ${ }^{2}$ and A. Petersen ${ }^{*}, 1$ \\ ${ }^{1}$ Institute of Neuroscience and Physiology, Department of Clinical Neuroscience and Rehabilitation/Ophthalmology and \\ ${ }^{2}$ Institute of Biomedicine, Department of Medical Chemistry and Cell Biology, The Sahlgrenska Academy at Gothenburg \\ University, Gothenburg, Sweden
}

\begin{abstract}
Aim: The aim of the study was to investigate changes in cell adhesion molecule expression in human lens epithelial cells (HLEC) subjected to glucocorticoids.

Methods: Human lens epithelial cells were exposed to different concentrations of dexamethasone for 24 hours. Cell adhesion molecule expression was studied by western blot and immunohistochemistry of vimentin, N-cadherin, Ecadherin, $\alpha$-catenin, $\beta$-catenin and $\gamma$-catenin. Expression of the glucocorticoid receptor (GR) was also studied. Cell morphology was examined by transmission electron microscopy (TEM).

Result: Expression of $\mathrm{N}$-cadherin, $\alpha$-catenin, $\beta$-catenin and GR was significantly decreased in dexamethasone exposed cells as compared to unexposed cells. No significant change in $\gamma$-catenin was present. Visualization of adhesion molecules, $\mathrm{N}$-cadherin and $\alpha$-catenin, by immunohistochemistry showed decreased antigen reactivity in dexamethasone exposed as compared to the unexposed cells. However, no change was seen for $\beta$-catenin and $\gamma$-catenin. E-cadherin was not detectable using western blot or immunohistochemistry.
\end{abstract}

TEM showed multilayering of cells, vacuole formation and appearance of electron-dense multivesicular bodies in HLEC exposed to $0,0.1,1,10$ and $100 \mu \mathrm{M}$ dexamethasone.

Conclusion: Glucocorticoids affect several adhesion molecules in lens epithelial cells, something that may contribute to the pathogenesis of posterior subcapsular opacification.

Keywords: Human lens epithelial cells, glucocorticoids, opacification, TEM, posterior subcapsular cataract, E-cadherin.

\section{INTRODUCTION}

Glucocorticoid-induced cataract is a common clinical condition. Although the association between topical and systemic steroid use and increased occurrence of posterior subcapsular cataract (PSC) has been known since 1960 [1], the mechanism behind this type of lens opacification has yet not been elucidated. Over the years, several mechanisms such as osmotic failure [2, 3], metabolic disturbances [3], protein adduct formation [3-6], conformational changes due to oxidative stress [3,6-8], and receptor mediated changes [3, 6, 8-11] have been proposed to account for PSC formation, but the results are inconclusive.

In recent years, aberrant cell migration, disrupted cell proliferation and differentiation, common features in PSC $[12,13]$, have been proposed to be due to perturbation of gene expression [14], reduction in E-cadherin [13] as well as the alteration of normal growth factor levels $[3,6]$.

Adherens junctions are protein complexes that form strong cell-cell contacts between adjacent cells. The classical view is that adherens junctions mediate adhesion between cells by linking the cytoplasmic tail of the calcium-

*Address correspondence to this author at the Institute of Neuroscience and Physiology, Department of Clinical Neuroscience and Rehabilitation/ Ophthalmology, PO Box 440, SE-405 30 Gothenburg, Sweden;

Tel: +46-31-773 33 94; E-mail: Anne.Petersen@gu.se dependent transmembrane protein, cadherin, directly to $\beta$ - or $\gamma$-catenin, which binds to $\alpha$-catenin that is connected to actin filaments. The stable intercellular adhesion provided by adherens junctions, maintain correct cell organization and homeostasis $[15,16]$. Disruption of this stable cell attachment could lead to disturbed cell migration.

In cultured chick embryonic lens epithelial cells, Ncadherin has been shown to be localized to adherens junctions [17-19]. Studies have also shown that inhibition of $\mathrm{N}$-cadherin leads to changes in expression of the cadherincatenin complex as well as disrupted connection to the actin cytoskeleton [20].

Studies have suggested that glucocorticoids exert their actions both directly on lens function as previously mentioned, as well as indirectly via the glucocorticoid receptor (GR) [2, 4, 7, 8, 10, 11, 21-23]. In the lens, the presence of a functional GR was discussed for long. However, recent studies have demonstrated that the lens, including the human lens, has a classical functional GR [11, 24].

Glucocorticoids bind to GRs in the cytoplasm and the hormone-receptor complex is then translocated into the nucleus $[23,25,26]$. In the nucleus, the GC-GR complex binds to glucocorticoid response elements (GRE) in the target gene to activate or repress gene expression [11, 23, 2628]. 
In a previous study from our group, we found an increase in proliferation as well as the apoptosis in native human lens epithelial cells after exposure to dexamethasone. The proapoptotic effect was not due to oxidative mechanisms, nor was it a GR-mediated effect [29].

In the present study, we have examined the effect of dexamethasone on cultured native human lens epithelial cells (HLEC) with respect to the adhesion molecule expression and GR-binding. Migration and morphology was investigated by western blot, immunohistochemistry and transmission electron microscopy.

\section{MATERIALS AND METHODS}

\section{Human Lens Epithelial Cell Culture}

Human lens epithelium specimens were obtained from lenses during cataract surgery at the Eye Clinic, Sahlgrenska University Hospital, Mölndal after informed consent. The study was approved by The Gothenburg University Ethics Committee and the tenets of the Declaration of Helsinki were followed. The human lens epithelium specimens, usually $5 \mathrm{~mm}$ in diameter, were put in eppendorf tubes containing culture medium (RPMI-1640), supplemented with $10 \%$ fetal calf serum, $100 \mathrm{U} \mathrm{ml}^{-1}$ penicillin, $0.1 \mathrm{mg} \mathrm{ml}^{-1}$ streptomycin and $2 \mathrm{mM}$ L-glutamine immediately after surgery. The lens epithelium specimens were transferred from the eppendorf tubes to 24-well culture dishes (TPP, Switzerland) in a humified $\mathrm{CO}_{2}$-incubator at $37^{\circ} \mathrm{C}$ and the lens epithelial cells (HLEC) started to proliferate. When confluent, the HLEC were subcultured by $0.25 \%$ trypsin/EDTA treatment, followed by resuspension in medium RPMI-1640 with $10 \%$ fetal calf serum, $100 \mathrm{U} \mathrm{ml}^{-1}$ penicillin, $0.1 \mathrm{mg} \mathrm{ml}^{-1}$ streptomycin and $2 \mathrm{mM} \mathrm{L-glutamine.}$

For each experiment, HLEC from two or more cell lines were used, each cell line containing cells from one individual, passage IV-VIII.

\section{Electrophoresis, Western Blot}

HLEC, exposed to 0 or $100 \mu \mathrm{M}$ dexamethasone in serum-free culture medium for 24 hours was rinsed in ice cold PBS, followed by lysis in modified NuPage 0.5\% lithium dodecyl sulphate (LDS) sample buffer (Invitrogen, Carlsbad USA).

The dexamethasone concentration used, was chosen according to dose response experiments of dexamethasone in a previous study from our group [29].

Whole cell lysate was used except for GR quantification where the cytoplasmic fraction was used. To separate the nucleus from the cytoplasm the cell lysate were centrifuged at $1200 \mathrm{~g}$ for 2 minutes. The cytoplasmic fraction was used for GR western blot analysis.

After subsequent heating of the cell lysate at $70^{\circ} \mathrm{C}$ for 10 minutes, protein concentration was determined using the BCA protein assay reagent (Pierce Perbio Science UK Limited, Cheshire, United Kingdom) with bovine serum albumin as standard. The samples were diluted to identical concentrations in NuPage LDS sample buffer and reducing agent (Invitrogen, Carlsbad USA) that was reduced to $10 \%$ of the total sample volume was added.
Equal amounts of protein $(10 \mu \mathrm{g})$ were separated on precast NuPAGE Bis-tris 4-12\% gradient minigels using NuPage MOPS as running buffer. For western blotting, proteins were transferred to nitrocellulose membranes followed by a blocking in 5\% non fat milk powder (NFM) in phosphate buffered saline (PBS) for 1 hour.

Primary antibodies used for Western blotting included mouse monoclonal anti-E-cadherin (no. 610181) (1:5000), anti-N-cadherin (1:10 000), anti- $\alpha$-catenin (1:500), anti- $\beta$ catenin (1:8000), anti- $\gamma$-catenin (1:8000) (all from BD Biosciences, USA), anti-vimentin (1:15 000) (Dako, Denmark), anti- $\beta$-actin (1:2000) (Sigma and polyclonal rabbit anti-GR (1:500) (Santa Cruz Biotechnology Inc., Europe).

For the adhesion molecule experiments, anti-vimentin was used as control. To detect small variations in gel loading between sample lanes in the GR experiments, anti- $\beta$-actin was used.

Primary antibody binding was detected with the corresponding secondary antibodies conjugated to horseradish peroxidase (Sigma Chemical, St Louis, MO USA).

Membranes were developed using the Amersham ${ }^{\mathrm{TM}}$ ECL Western blotting detection reagents (GE Healthcare, UK) and exposed to Amersham ${ }^{\mathrm{TM}}$ Hyperfilm ECL (GE Healtcare, UK), followed by densitometry analysis using ImageJ software version 1.37 (National Institute of Health, USA).

\section{Immunohistochemistry}

For immunohistochemistry labelling, cells were seeded in chamber slides (Lab-Tek ${ }^{\mathrm{TM}}$ Nalge Nunc International, Rochester, NY, USA). When semiconfluent, the cells were exposed to 0 or $100 \mu \mathrm{M}$ dexamethasone for 24 hours followed by fixation in $4 \%$ paraformaldehyde solution $(\mathrm{pH}$ 7.4) for 15 minutes. The fixed and rinsed cells were preincubated in 5\% NFM in phosphate buffered saline (PBS) for $30 \mathrm{~min}$ in room temperature. The cells were incubated with primary antibodies overnight at $+4^{\circ} \mathrm{C}$. Corresponding primary antibodies used in the western blot experiments were used at concentrations; mouse monoclonal antivimentin, (1:1000) anti-N-cadherin (1:100), anti- $\alpha$-catenin (1:100), anti- $\beta$-catenin (1:100), anti- $\gamma$-catenin $(1: 100)$, rabbit polyclonal anti- GR (1:100), anti-E-cadherin (no. 610181, 610404), (1:100) (all from BD Biosciences, USA), anti-Ecadherin (1:100) (Invitrogen, Camarillo CA USA) and fluorescein isothiocyanate (FITC) conjugated phalloidin (1:100) (Sigma Chemical, St Louis, MO USA). After subsequent rinse in PBS, the cells were incubated with biotin-conjugated matching secondary antibodies for 1 hour at room temperature followed by incubation with streptavidin conjugated FITC (Vector Laboratories Burlingame, CA) according to standard immunohistochemistry protocol.

Further, cell nuclei were stained with Hoechst 33342 (Hoechst, Frankfurt Germany) at a final concentration of 5 $\mu \mathrm{g} \mathrm{ml}^{-1}$ in a PBS buffer for $15 \mathrm{~min}$. After being washed in PBS, the slides were mounted with Vectashield mounting media (Vector Laboratories Burlingame, CA) and immediately viewed using a fluorescence microscope (Nikon C1 Eclipse TE300; Nikon). 


\section{Transmission Electron Microscopy}

HLEC cultured on a Transwell membrane were exposed to dexamethasone for 24 hours followed by fixation in Karnowsky fixative (2\% paraformaldehyde, $2.5 \%$ glutaraldehyde, $0.01 \%$ sodium azide in $0.05 \mathrm{M}$ sodium cacodylate) for 2 hours at $4^{\circ} \mathrm{C}$. The cells were rinsed in 0.15 $\mu \mathrm{M}$ sodium cacodylate and postfixed in $1 \%$ osmium tetroxide $\left(\mathrm{OsO}_{4}\right)$ and $1 \%$ potassium ferrocyanide $\left(\mathrm{K}_{4} \mathrm{Fe}(\mathrm{CN})_{6}\right)$ for 2 hours at $4^{\circ} \mathrm{C}$. Contrast was enhanced by $0.5 \%$ uranyl acetate for 1 hour in darkness at room temperature. After dehydration, the filters with attached cells were embedded in Agar 100 resin (Agar Scientific LTD, Essex, England). Ultrathin transverse sections (60-70 nm) of the filters with attached cells were contrasted with uranyl acetate and lead citrate before examination in a LEO 912AB transmission electron microscope (Carl Zeiss, Oberkochen, Germany). Digital image files were captured with a MegaView III camera (Soft Imaging Systems, Münster, Germany).

\section{Statistics}

Statistical analysis on densitometry results from western blot experiments was performed using independent-samples t-test. As software, SPSS 11.0.4 (SPSS Inc., Chicago, Il) were used. Experiments were run at least three times to confirm reproducibility and representative results are shown.

\section{RESULTS}

\section{Effect of Dexamethasone on Protein Expression Quantified by Western Blot}

Western blot and densitometry analysis showed decreased $\mathrm{N}$-cadherin, $\alpha$-catenin, $\beta$-catenin and GR expression in dexamethasone exposed HLEC as compared to the unexposed cells (Figs. 1, 2). The result indicates a decreased cellular adherens.
No significant change in, $\gamma$-catenin or vimentin expression was present (Fig. 1). Vimentin was used as positive control for adhesion and $\beta$-actin was used as loading control in the GR experiments. E-Cadherin was not detectable.

\section{Immunohistochemical Analysis}

Immunohistochemical analysis showed a declined expression of $\mathrm{N}$-cadherin and $\alpha$-catenin (Fig. 3B, D) in HLECs exposed to dexamethasone as compared to the unexposed cells (Fig. 3A, C). No change in antigen expression of dexamethasone exposed cells labelled with anti- $\beta$-catenin or anti- $\gamma$-catenin (Fig. 3F, $\mathbf{H}$ ) as compared to the unexposed cells (Fig. 3E, G) was evident.

Translocation of the GC-GR complex to the nucleus was present to a larger extent in the dexamethasone exposed HLECs (Fig. 4B) as compared to the unexposed cells (Fig. 4A). Immunostaining for E-cadherin was negative (not shown).

\section{Morphological Changes as Viewed by Transmission Electron Microscopy}

Control HLEC grew as monolayers on the filters. The cells displayed numerous mitochondria with regularly spaced cristae, well developed and branching rough endoplasmic reticulum, and rather prominent and vesicle rich Golgi regions (Fig. 5A). HLEC exposed to 0.1, 1, 10 and $100 \mu \mathrm{M}$ dexamethasone exhibited dose-dependent morphological changes consisting of vacuole formation and increasing numbers of multivesicular bodies. The latter were most numerous and irregularly shaped in high-dose dexamethasone cells. They contained a very electron-dense material including packed membranes and numerous vesicles. Interestingly, an apparent rearrangement of membrane into dense whirls was seen in association with some mitochondria (Fig. 5B-D). At 1,10 and $100 \mu \mathrm{M}$,

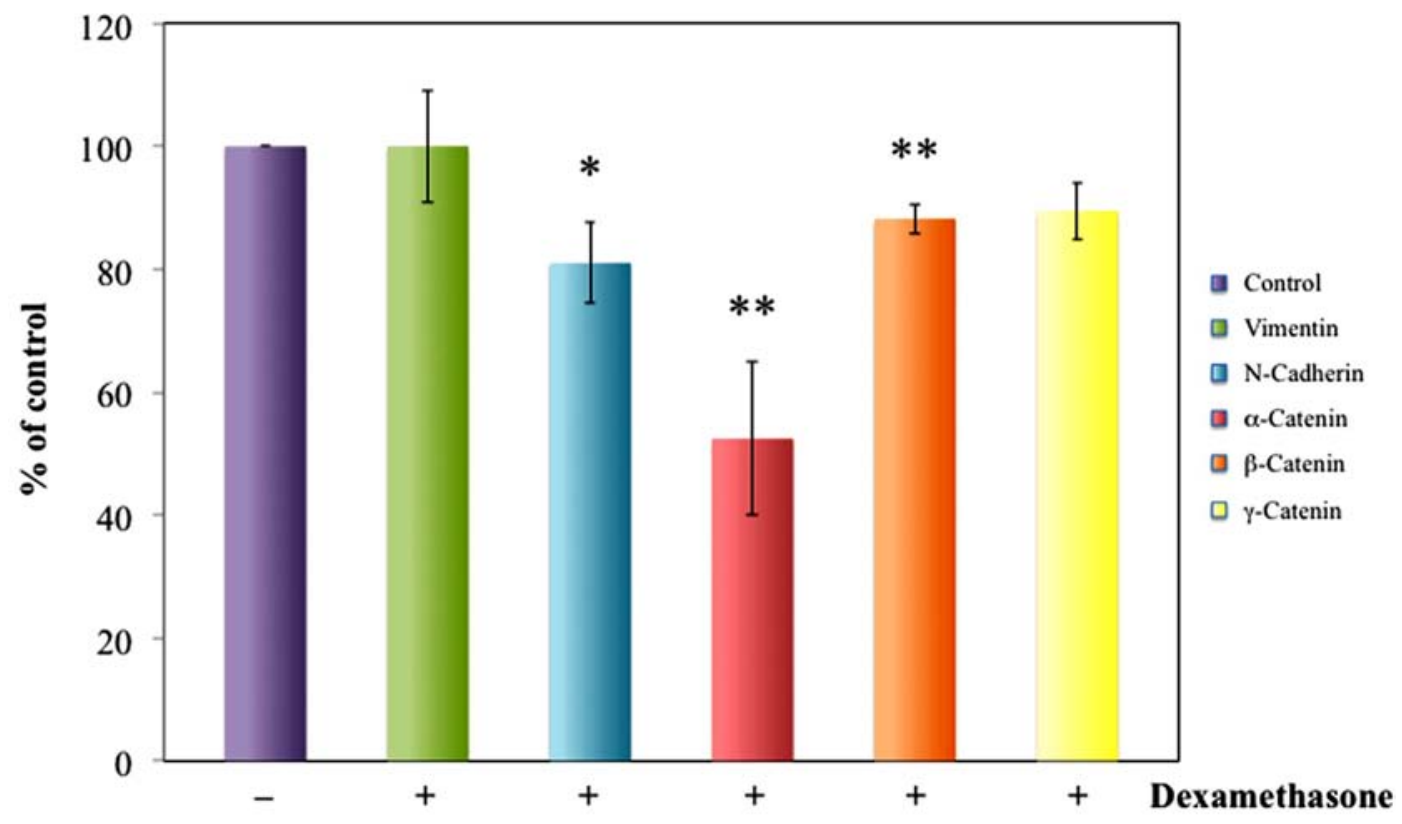

Fig. (1). Densitometric analysis of western blot reveals significantly decreased N-cadherin $\alpha$-catenin and $\beta$-catenin expression in HLEC exposed to dexamethasone for 24 hours as compared to unexposed cells. Dexamethasone exposure did not change $\gamma$-Catenin or vimentin expression. Vimentin was used as positive control for adhesion molecule detection. $* \mathrm{P}<0.05, * * \mathrm{P}<0.01$. 
multilayering of cells was also evident (Fig. 5C-E).

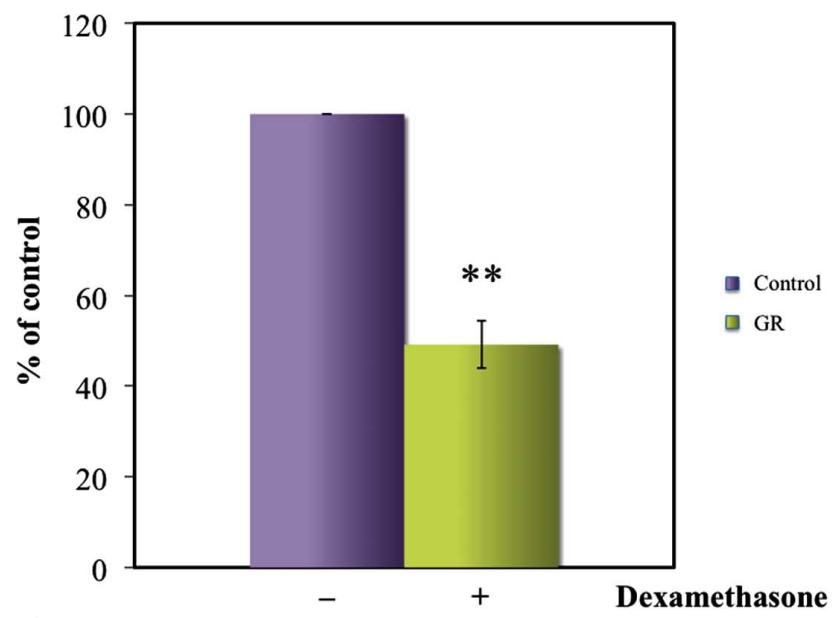

A

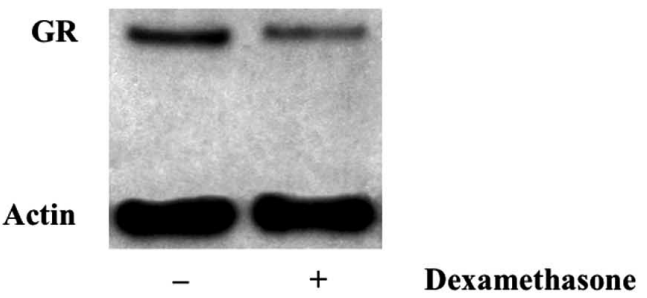

B

Fig. (2). Densitometry of GR bands in western blots showed a significant decrease of GR in the cytoplasm of dexamethasone exposed cells as compared to the unexposed (A). Western blot of HLEC presenting significantly weaker GR expression in HLEC exposed to $100 \mu \mathrm{M}$ dexamethasone as compared to unexposed cells. $\beta$-actin was used as loading control (B). ${ }^{*} \mathrm{P}<0.05$.

\section{DISCUSSION}

Glucocorticoids are frequently used in clinical practice because of their anti-inflammatory and anti-immunologic actions to treat diseases such as allergies, rheumatic and autoimmune conditions.

Glucocorticoids have many diverse effects, including potentially harmful side effects such as causing lens opacities in the posterior pole of the lens (posterior subcapsular cataract, PSC). However, the mechanism behind these glucocorticoid-induced opacities is yet not elucidated. In this study, we examined effects of dexamethasone on cell adhesion, migration and glucocorticoid receptor binding.

We found a decrease in the adhesion molecule $\mathrm{N}$ cadherin as well as decreased expression of $\alpha$-catenin and $\beta$ catenin, adhesion molecules linking cadherin to the actin cytoskeleton, indicating a reduction of the cell-cell binding capacity, which could lead to altered cell migration. A study by Ferreira-Cornwell et al, showed that when N-cadherin was blocked, $\alpha$-catenin and $\beta$-catenin expression were also decreased, while $\gamma$-catenin (plakoglobin) was upregulated to compensate for the loss of $\mathrm{N}$-cadherin, $\alpha$ - and $\beta$-catenin [20]. In our study, $\gamma$-catenin expression was unchanged in cells exposed to dexamethasone as compared to the unexposed cells while exposure to dexamethasone decreased $\mathrm{N}$-cadherin, $\alpha-$ and $\beta$-catenin expression. However, the downregulation of $\mathrm{N}$-cadherin, $\alpha$ - and $\beta$-catenin in our study may not have been as pronounced as in Ferreira-Cornwell's study which could explain the difference in $\gamma$-catenin expression between the two studies.

However, we could not detect any E-cadherin expression by western blot or immunohistochemistry. Studies in other species or in transfected human lens epithelial cell lines have detected E-cadherin in the lens [30-33]. In contrast, as in the present study, Nishi et al. did not find E-cadherin in native human lens epithelial cells [34]. The discrepancy in Ecadherin expression may be due to different species and transfected versus native cells.

Several studies have verified a functional GR in the lens $[6,10,11,23,24,28]$ and that the changes in signalling pathways (MAPK and PI3K/AKT) in the lens are due to specific GR activation [23].

When GC binds to the GR, the GC-GR complex is translocated from the cytoplasm to the nucleus. In the present study, the nuclear fraction of the cell lysate was removed, so that only non-liganded GR in the cytoplasm was measured. We found a downregulation of GR expression indicating GC-GR complex binding, hence demonstrating an active glucocorticoid receptor.

Some studies propose that most glucocorticoid-related effects are directly or indirectly mediated by GRs $[9,11,23$, $24,28]$, whereas other studies suggest that glucocorticoids mainly exert their actions through receptor-independent mechanisms $[4,5,9,21]$.

An interesting feature of dexamethasone-exposed HLEC was the dose-dependent accumulation of membrane-delimited electron-dense material found in the cytoplasm. These multivesicular bodies have features of autophagosomes in which vesicles that may represent membrane-wrapped organelles were found. The electron-dense content of these inclusion bodies may also be due to aggregated proteins resulting from protein-steroid adduct formation, since conformational changes of lens proteins due to binding of steroid adducts to lens proteins have been implicated in the formation of the steroid-induced cataract [4]. However, this cataractogenic mechanism has been questioned $[3,8,35]$.

Transmission electron microscopy also demonstrated the occurrence of multilayered cells after exposure to 1,10 and 100 $\mu \mathrm{M}$ dexamethasone. In the cells exposed to lower concentrations or in unexposed cells, no multilayering was evident. The appearance of multilayered HLEC after dexamethasone exposure is indicative of a dysregulation of proliferation, differentiation or migration of the cells, all of which have been discussed as pathogenic mechanisms behind PSC formation [36, 37]. Since there is a direct link between the prolonged use of steroids and this particular type of cataract, the present findings are of great importance for elucidating the mechanism behind cortisone cataract. Studies have shown that lens differentiation, as well as proliferation are controlled by growth factors in the vitreous humour [38]. Alterations of these growth factors by corticosteroids have been suggested to disturb lens differentiation, providing a possible mechanism for how steroids affect lens fibre formation, thereby leading to PSC [3]. 

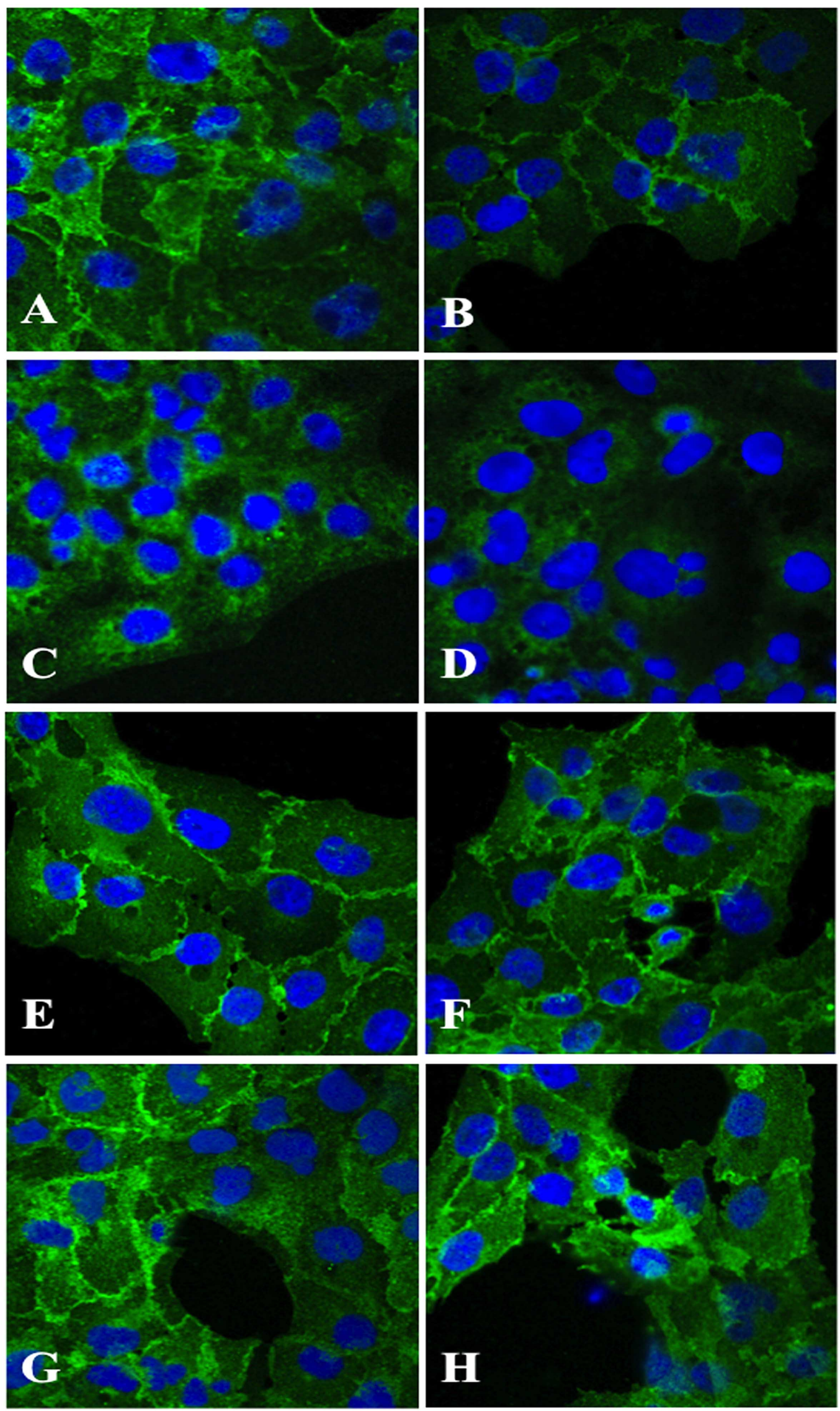

Fig. (3). Immunohistochemical staining of HLEC exposed $100 \mu \mathrm{M}$ dexamethasone $(\mathbf{B}, \mathbf{D}, \mathbf{F}, \mathbf{H})$ for 24 hours indicated a decline in antigen reactivity of $\mathrm{N}$-cadherin $(\mathbf{B})$ and $\alpha$-catenin $(\mathbf{D})$, whereas $\beta$-catenin $(\mathbf{F})$ and $\gamma$-Catenin $(\mathbf{H})$ showed no change in antigen expression as compared to corresponding unexposed cells $(\mathbf{A}, \mathbf{C}, \mathbf{E}, \mathbf{G})$. Original magnification 1000x 

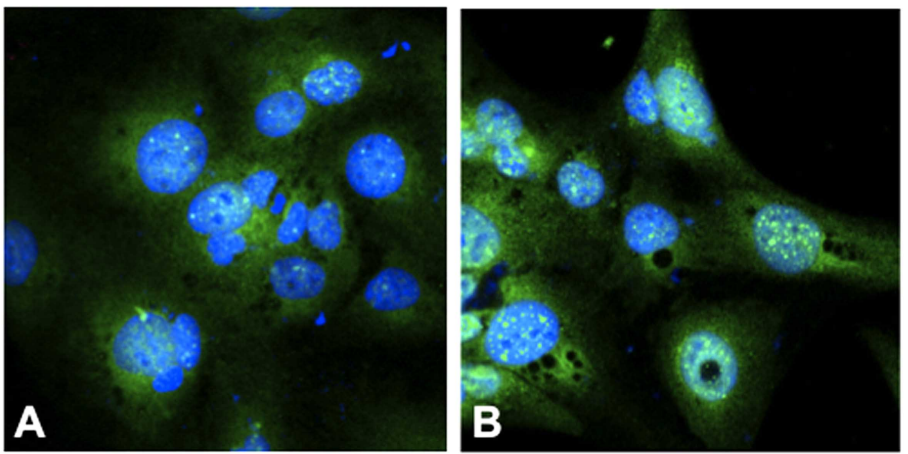

Fig. (4). Immunohistochemistry of the glucocorticoid receptor (GR) showed an increase of GR in the nucleus of (B) dexamethasone exposed cells $(100 \mu \mathrm{M})$ as compared to $(\mathbf{A})$ unexposed cells, indicative of translocalisation of the CG-GR complex to the nucleus. The cell nuclei is stained with Hoechst 33342 (blue), and GR with FITC (green) Original magnification 1000x.
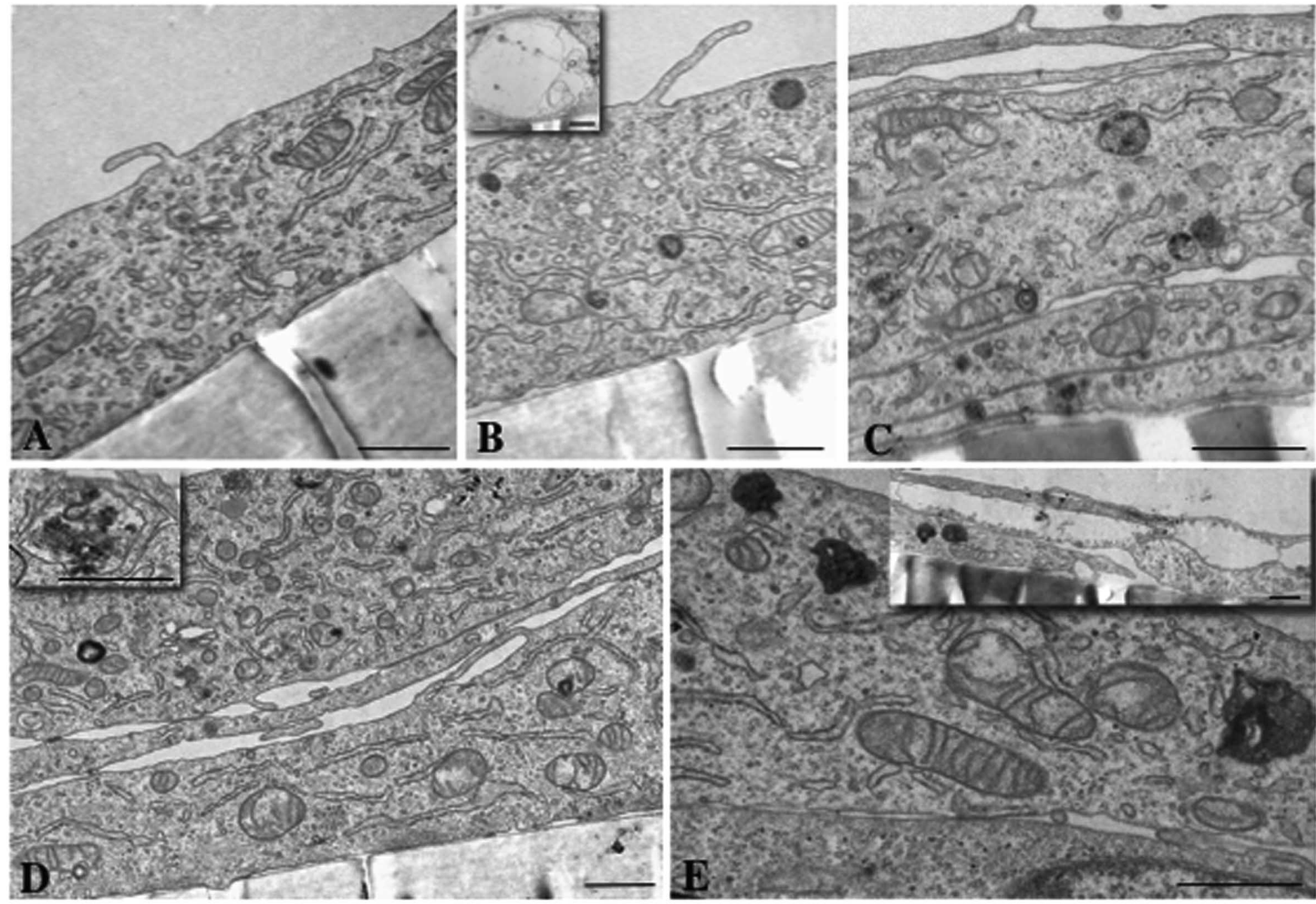

Fig. (5). Morphological changes viewed by transmission electron microscopy. A dose-dependent increase in multivesicular bodies in HLEC after exposure to $0.1 \mu \mathrm{M}(\mathbf{B}), 1 \mu \mathrm{M}(\mathbf{C}), 10 \mu \mathrm{M}(\mathbf{D})$ and $100 \mu \mathrm{M}(\mathbf{E})$ dexamethasone for 24 hours was evident. Control cells, $0 \mu \mathrm{M}$ dexamethasone, are shown in (A). Enlargement of a multivesicular body is shown as an inset picture in (D). Multilayering of cells, present after 1, 10 and $100 \mu \mathrm{M}$ dexamethasone exposure, is shown in $(\mathbf{C}),(\mathbf{D})$ and $(\mathbf{E})$. Vacuoles also occurred, being more frequent in number and size with increasing concentration (see inset in picture $\mathbf{B}$ and $\mathbf{E}$ ). Scale bar $=1 \mu \mathrm{M}$.

The present study indicates that several mechanisms may be involved in PSC formation. However, whether the aberrant cell migration due to the down regulation of adhesion molecules after dexamethasone exposure is a direct receptor mediated effect or an indirect effect caused by GR modulation of transcription of other genes, is yet to be elucidated. Non-receptor mediated effects may also be involved in the pathogenesis of steroid-induced cataract.

\section{ACKNOWLEDGEMENTS}

This study was supported by the Göteborg Medical Society, the Swedish Medical Society, the Swedish Society for Medical Research, Karin Sandquist Foundation, Stiftelsen Handlanden Herman Svensson Foundation, Knut and Alice Wallenberg Foundation, Föreningen de Blindas Vänner and Kronprinsessan Margaretas Arbetsnämnd för Synskadade and Ögonfonden. 


\section{CONFLICT OF INTEREST}

Declared none.

\section{REFERENCES}

[1] Black RL, Oglesby RB, Von Sallmann L, Bunim JJ. Posterior subcapsular cataracts induced by corticosteroids in patients with rheumatoid arthritis. JAMA 1960; 174: 166-71.

[2] Mayman CI, Miller D, Tijerina ML. In vitro production of steroid cataract in bovine lens. Part II: measurement of sodium-potassium adenosine triphosphatase activity. Acta Ophthalmol 1979; 57(6): 1107-16.

[3] Jobling AI, Augusteyn RC. What causes steroid cataracts? A review of steroid-induced posterior subcapsular cataracts. Clin Exp Optom 2002; 85(2): 61-75.

[4] Bucala R, Gallati M, Manabe S, Cotlier E, Cerami A. Glucocorticoid-lens protein adducts in experimentally induced steroid cataracts. Exp Eye Res 1985; 40(6): 853-63.

[5] Manabe S, Bucala R, Cerami A. Nonenzymatic addition of glucocorticoids to lens proteins in steroid-induced cataracts. J Clin Invest 1984; 74(5): 1803-10.

[6] James ER. The etiology of steroid cataract. J Ocul Pharmacol Ther 2007; 23(5): 403-20.

[7] Costagliola C, Iuliano G, Menzione M, Apponi-Battini G, Auricchio G. Effect of topical glucocorticoid administration on the protein and nonprotein sulfhydryl groups of the rabbit lens. Ophthalmic Res 1987; 19(6): 351-6.

[8] Dickerson JE Jr, Dotzel E, Clark AF. Steroid-induced cataract: new perspective from in vitro and lens culture studies. Exp Eye Res 1997; 65(4): 507-16.

[9] Jobling AI, Augusteyn RC. Is there a glucocorticoid receptor in the bovine lens? Exp Eye Res 2001; 72(6): 687-94.

[10] James ER, Robertson L, Ehlert E, Fitzgerald P, Droin N, Green DR. Presence of a transcriptionally active glucocorticoid receptor alpha in lens epithelial cells. Invest Ophthalmol Vis Sci 2003; 44(12): 5269-76.

[11] Gupta V, Wagner BJ. Search for a functional glucocorticoid receptor in the mammalian lens. Exp Eye Res 2009; 88(2): 248-56.

[12] Streeten BW, Eshaghian J. Human posterior subcapsular cataract. A gross and flat preparation study. Arch Ophthalmol 1978; 96(9):1653-8.

[13] Lyu J, Kim JA, Chung SK, Kim KS, Joo CK. Alteration of cadherin in dexamethasone-induced cataract organ-cultured rat lens. Invest Ophthalmol Vis Sci 2003; 44(5): 2034-40.

[14] James ER, Fresco VM, Robertson LL. Glucocorticoid-induced changes in the global gene expression of lens epithelial cells. J Ocul Pharmacol Ther 2005; 21(1): 11-27.

[15] Falk MM. Adherens junctions remain dynamic. BMC Biol 2010; 8:34.

[16] Lampugnani MG. Endothelial adherens junctions and the actin cytoskeleton: an 'infinity net'? J Biol 2010; 9(3): 16.

[17] Volk T, Geiger B. A-CAM: a 135-kD receptor of intercellular adherens junctions. I. Immunoelectron microscopic localization and biochemical studies. J Cell Biol 1986; 103(4): 1441-50.

[18] Volk T, Geiger B. A-CAM: a 135-kD receptor of intercellular adherens junctions. II. Antibody-mediated modulation of junction formation. J Cell Biol 1986; 103(4): 1451-64.

[19] Atreya PL, Barnes J, Katar M, Alcala J, Maisel H. N-cadherin of the human lens. Curr Eye Res 1989; 8(9): 947-56.
[20] Ferreira-Cornwell MC, Veneziale RW, Grunwald GB, Menko AS $\mathrm{N}$-cadherin function is required for differentiation-dependent cytoskeletal reorganization in lens cells in vitro. Exp Cell Res 2000; 256(1): 237-47.

[21] Bucala R, Manabe S, Urban RC, Cerami A. Nonenzymatic modification of lens crystallins by prednisolone induces sulfhydryl oxidation and aggregate formation: in vitro and in vivo studies. Exp Eye Res 1985; 41(3): 353-63.

[22] Jobling AI, Stevens A, Augusteyn RC. Binding of dexamethasone by alpha-crystallin. Invest Ophthalmol Vis Sci 2001; 42(8): 182932.

[23] Gupta V, Awasthi N, Wagner BJ. Specific activation of the glucocorticoid receptor and modulation of signal transduction pathways in human lens epithelial cells. Invest Ophthalmol Vis Sci 2007; 48(4): 1724-34.

[24] Gupta V, Wagner BJ. Expression of the functional glucocorticoid receptor in mouse and human lens epithelial cells. Invest Ophthalmol Vis Sci 2003; 44(5): 2041-6.

[25] Baxter JD, Rousseau GG. Glucocorticoid hormone action: an overview. Monogr Endocrinol 1979; 12: 1-24.

[26] Slater EP, Anderson T, Cattini P, et al. Mechanisms of glucocorticoid hormone action. Adv Exp Med Biol 1986; 196: 6780 .

[27] Burnstein KL, Bellingham DL, Jewell CM, Powell-Oliver FE, Cidlowski JA. Autoregulation of glucocorticoid receptor gene expression. Steroids 1991; 56(2): 52-8.

[28] Gupta V, Galante A, Soteropoulos P, Guo S, Wagner BJ. Global gene profiling reveals novel glucocorticoid induced changes in gene expression of human lens epithelial cells. Mol Vis 2005; 11: 1018-40.

[29] Petersen A, Carlsson T, Karlsson JO, Jonhede S, Zetterberg M. Effects of dexamethasone on human lens epithelial cells in culture. Mol Vis 2008; 14: 1344-52.

[30] Xu L, Overbeek PA, Reneker LW. Systematic analysis of E-, Nand P-cadherin expression in mouse eye development. Exp Eye Res 2002; 74(6): 753-60.

[31] Pontoriero GF, Smith AN, Miller LA, Radice GL, West-Mays JA, Lang RA. Co-operative roles for E-cadherin and N-cadherin during lens vesicle separation and lens epithelial cell survival. Develop Biol 2009; 326(2): 403-17

[32] Stump RJ, Lovicu FJ, Ang SL, Pandey SK, McAvoy JW. Lithium stabilizes the polarized lens epithelial phenotype and inhibits proliferation, migration, and epithelial mesenchymal transition. J Pathol 2006; 210(2): 249-57.

[33] Choi J, Park SY, Joo CK. Transforming growth factor-beta1 represses E-cadherin production via slug expression in lens epithelial cells. Invest Ophthalmol Vis Sci 2007; 48(6): 2708-18.

[34] Nishi O, Nishi K, Akaishi T, Shirasawa E. Detection of cell adhesion molecules in lens epithelial cells of human cataracts. Invest Ophthalmol Vis Sci 1997; 38(3): 579-85.

[35] Jobling AI, Augusteyn RC. Steroid adduct formation with lens crystallins. Clin Exp Optom 1999; 82(4): 130-6.

[36] Eshaghian J, Streeten BW. Human posterior subcapsular cataract. An ultrastructural study of the posteriorly migrating cells. Arch Ophthalmol 1980; 98(1): 134-43.

[37] Nagata M, Matsuura H, Fujinaga Y. Ultrastructure of posterior subcapsular cataract in human lens. Ophthalmic Res 1986; 18(3): $180-4$.

[38] McAvoy JW, Chamberlain CG. Fibroblast growth factor (FGF) induces different responses in lens epithelial cells depending on its concentration. Development 1989; 107(2): 221-8. 